Mesopotamia J. of Agric.

Vol. (33), No

(3) 2005

\title{
BLOOD GLUCOSE RESPONSE AND GLYCEMIC INDEX OF BREADS AND SOME WHEAT PRODUCTS IN NORMAL HUMAN SUBJECTS
}

\author{
Abdullah M. Thannoun Adnan A. M. M. Al-kubati \\ College of Agric. and Forestry, Mosul Univ., Iraq
}

\begin{abstract}
Blood glucose response and glycemic Index (GI) for whole wheat loaf, white flour loaf and white flour bread "Tannour bread" and wheat products such as burghul, habbiyah, reshta and spaghetti in normal human subjects using glucose as standard were studied. Twenty one normal male human subjects (age 22-35 years and body mass index, BMI $22-26 \mathrm{~kg} / \mathrm{m}^{2}$ ) were chosen as volunteers for this study. The subjects were divided randomly into seven groups where each three of the subjects could submit to the experiments. After 12 hours overnight fast, each subject was tested for blood glucose at zero time before given the test food or glucose standard in an amount to provide $50 \mathrm{~g}$ carbohydrate. Glycemic response, Incremental Area Under the Curve (IAUC) and Glycemic index (GI) were determined and calculated. The results showed that there were no significant $(\mathrm{P}<0.05)$ differences in GI between the three kinds of breads $(61,69$ and 64 for each whole wheat loaf, white flour loaf and white flour Tannour bread, respectively), however, there were a significant $(\mathrm{P}<0.05)$ differences between each kind of bread and glucose standard (100). Further, the GI values of all kinds of bread were higher than that of other wheat products $(41,40,26$ and 40 for burghul, habbiyah, reshta and spaghetti, respectively). It was concluded that food processing method including changing in food components of the product resulted in variable blood glucose response. It was also concluded that the above wheat products could be used efficiently in diet management of Type II diabetes.
\end{abstract}

\section{INTRODUCTION}

Glycemic Index (GI) refers to the relative rise of blood glucose response after consumption a certain food containing a definite amount of carbohydrate (Jenkins et al., 1981 and Wolever et al., 1991). According to this concept foods were classified and ranked according to the glycemic response they produce for a given amount of carbohydrate when indexed to glucose solution or white bread (Jenkins et al., 1981). Different foods can have markedly different GI (Foster-Powell and Brand-Miller, 1995 and Foster-Powell et al., 2002) and the values may be useful in management or in planning therapeutic diets for diabetes. Since then, studies have shown that consumption of a diet with a low GI was associated with improvement of metabolic control of diabetes (Jenkins et al., 1988 and Wolever et al., 1992).

One of the major justifications for the inclusion of cereals especially wheat in the diet of the human in the world is their ability to supply a wide variety of nutrients and moderate energy at low cost (Roderuck and Fox, 1987 and Smolin and Grosvenor, 2003). The most common and traditional product made from wheat is the principal one being baked leavened bread in the world and unleavened baked bread the more common form in developing countries (Johnson and Mattern, 
1987). For this reason, no food is so versatile as bread in human nutrition even in health or disease over the world. In Iraq and some other countries additional wheat products like burghul, habbiyah and reshta etc are produced by various food processes.

Part of Ph D. thesis of the second auther

Received 12/5/2005 Accepted 3/8/2005

It has bean noticed that the glycemic responses to different starchy foods such as bread and some cereal products were unpredictable concerning to the type and content of their carbohydrate (Crapo et al., 1981 and Jenkins et al., 1981). Different values of GI for normal subjects were found for different kinds of whole wheat and white breads ranging from $69 \pm 10$ (Jenkins et al., 1981; Walker and Walker, 1984 and Foster-Powell and Brand-Miller, 1995) to 90 \pm 10 (Jenkins et al., 1987; Wolever et al., 1994 and Foster-Powell and Brand-Miller, 1995). Since then, different factors have been confirmed to affect glycemic response and indices for various foods such as the component and the nature of the starch (Behall et al., 1988; Bornet et al., 1987 and Russell et al., 1989), physical and chemical properties of the nutrients resulted by food processing (O'Dea et al., 1980 and Jenkins et al., 1982) and presence of fiber, fat and protein in the food (Wolever and Bolegnesi , 1996a and Bourdon et al., 1999). Despite of the controversy, most studies have found that GI concept is important, reproducible and beneficial in the dietary management of diabetes (Jenkins et al., 1981, Jenkins et al., 1985; Wolever et al., 1991 and Foster-Powell et al., 2002). The aim of this study was to evaluate the blood glucose response through out estimation of GI values for some local wheat loaf or bread and some traditional wheat products, namely burghul, habbiyah, reshta and spaghetti by human subjects.

\section{MATERIALS AND METHODS}

Foods: The following cereals and cereal products, white flour loaf, whole wheat loaf, white flour bread (Tannour made) and some local and traditional wheat products such as burghul, habbiyah, reshta (roasted spaghetti) and spaghetti were used in this study. Wheat (Triticum aestivum) was obtained from Iba Center for Agricultural Researches, Mosul Iraq. Burghul, habbiyah, reshta and spaghetti were purchased from local market in Mosul City- Iraq. Grains were sorted and washed with tap water then dried in Cabinet dryer with hot air at $55^{\circ} \mathrm{C}$ for 48 hours. Wheat grains were grinded in Quadrume Junior Mill, Brabander- Germany and the flour was packed in polyethylene sacs and stored in the refrigerator until used in the next step. Burghul and habbiyah were cleaned and sorted from Stones and unusual materials and packed in polyethylene sacs and stored in the refrigerator until analysis.

Chemical Analysis: Approximate analysis was performed to determine the moisture, protein, fat, fiber, ash and carbohydrate in wheat, wheat flour and their products (Table 1).

Table 1: Chemical composition of wheat flours and some cereal products on dry weight bases $(\mathrm{g} / 100 \mathrm{~g})$

\begin{tabular}{|l|c|c|c|c|c|}
\multirow{2}{*}{ Foods } & \multicolumn{4}{|c|}{ Components } \\
\cline { 2 - 5 } & Protein & Fat & Fiber & Ash & Carbohydrate* \\
\hline
\end{tabular}




\begin{tabular}{|l|c|c|c|c|c|}
\hline White flour & IY.97 & 0.86 & 0.44 & 0.84 & 84.90 \\
\hline Whole wheat flour & 12.80 & 1.97 & 2.94 & 1.46 & 80.52 \\
\hline Burghul & 15.13 & 1.90 & 2.22 & 1.19 & 79.56 \\
\hline Habbiyah & 13.56 & 1.20 & 1.92 & 1.22 & 81.33 \\
\hline Reshta & 15.30 & 1.49 & 2.51 & 1.75 & 82.10 \\
\hline Spaghetti & 11.56 & 1.15 &. $\mathrm{r}$ & 0.68 & 86.25 \\
\hline
\end{tabular}

*by difference. The numbers are average of three samples.

Moisture was determined according to the method of AOAC (1980) by using rapid moisture tester made by Brabander, Germany at $105^{\circ} \mathrm{C}$ until constant weight. Protein was determined according to the procedures mentioned by Pearson (1973) using Macrokjeldahl method. Fat was determined according to the procedures mentioned by Pearson (1976) using Soxhlet method. Crude fiber was determined according to the procedures mentioned by Pearson (1973). Ash determination was performed according to the method of AOAC (1980).

Determination of Gelatinization: Degree of temperature of gelatinization for wheat, wheat flour and their products was measured using Viscograph according to the method of AACC (1976).

Apparent and Total Amylose Determination: Apparent amylose was determined according to the method of Morrison et al. (1988) using Urea Dimethyl sulphoxide solution. Apparent amylose was estimated by spectrophotometer at $630 \mathrm{~nm}$ and using the following equation:

Apparent Amylose \% = 29.41 X Blue value - 5.23

Whereas Total Amylose was determined using Urea Dimethyl Solphoxide solution after removing the fat materials by Ethyl alcohol and reading at $630 \mathrm{~nm}$ then using the same equation.

Bread preparation: Three kinds of loaf or breads were made, white flour loaf, whole wheat loaf and white flour bread (Tannour style made). Certain amounts of wheat flour or foods were weighted as shown in Table 2 to make the bread and consumed foods.

Table 2: Components and composition of diets prepared for blood glucose response

\begin{tabular}{|c|c|c|c|c|c|c|c|}
\hline \multirow{2}{*}{ Foods } & \multirow{2}{*}{$\begin{array}{l}\text { Weight of food } \\
\text { before baking } \\
\text { or cooking, } g\end{array}$} & \multicolumn{5}{|c|}{ Components, $\mathrm{g}$} & \multirow{2}{*}{$\begin{array}{l}\text { Weight of } \\
\text { consumed } \\
\text { food, } \mathrm{g}\end{array}$} \\
\hline & & $\mathrm{CHO}$ & Protein & Fat & Fiber & Ash & \\
\hline White flour loaf & 58.9 & 50 & 7.63 & 0.50 & 0.26 & 0.49 & 102 \\
\hline Whole wheat loaf & 62.1 & 50 & 7.92 & 1.22 & 1.82 & 0.90 & 100 \\
\hline $\begin{array}{l}\text { White flour bread } \\
\text { (Tannoor) }\end{array}$ & 58.9 & 50 & 7.63 & 0.50 & 0.26 & 0.49 & 98 \\
\hline Burghul & 62.9 & 50 & 9.60 & 1.20 & 1.41 & 1.25 & 182 \\
\hline Habbia & 61.5 & 50 & 8.28 & 0.73 & 1.17 & 0.74 & 167 \\
\hline Reshta & 60.9 & 50 & 9.70 & 0.94 & 1.59 & 1.10 & 206 \\
\hline Spaghetti & 58.0 & 50 & 7.40 & 0.74 & 0.23 & 0.43 & 150 \\
\hline
\end{tabular}

The numbers are average of three samples. 
Dough was made by adding $2 \mathrm{~g}$ fresh yeast, $1.5 \mathrm{~g} \mathrm{NaCl}$ and $50 \mathrm{ml}$ worm water until complete fermentation. The fermented dough was baked in oven at $250{ }^{\circ} \mathrm{C}$ or in special local Tannour as flat bread. The loaves or bread were divided in pieces to contain $50 \mathrm{~g}$ carbohydrates as indicated in Table 2.

Ready to eat burghul, habbiyah, reshta and spaghetti: Certain amounts of foods were weighted as shown in Table 2 to have $50 \mathrm{~g}$ carbohydrates in the final consumed foods. The weighed foods were cooked with adequate amount of water and $2 \% \mathrm{NaCl}$ for 15-30 min. In case of reshta and spaghetti the free cooking water was drained to prepare local style cooking for these foods.

All loaves, bread and ready to eat burghul, habbiyah, reshta and spaghetti were prepared freshly when they consumed and performed the experiment.

Subjects: Twenty one male normal human subjects (age 22-35 years and Body Mass Index, BMI $22-26 \mathrm{~kg} / \mathrm{m}^{2}$ ) were chosen as volunteers in this study. The subjects were randomly divided into seven groups where each three of the subjects could submit to the experiment. After 12 hours overnight fast, the subject was tested for blood glucose at zero time before given in an amount of test food containing $50 \mathrm{~g}$ carbohydrate. Blood glucose was determined after 15, 30, 45, 60, 90 , and 120 minutes. The same method was performed by the subject by ingestion $50 \mathrm{~g}$ of glucose dissolved in $250 \mathrm{ml}$ water.

Measurement of Blood Glucose Response: Blood glucose was determined by using glucose tester Device made by Johnson and Johnson Co., Lifescon, USA. Blood samples were taken from subject finger using finger prick capillary. Glycemic Index (GI) for each diet was determined by calculation of Incremental Area Under two hours of blood glucose response or Curve (IAUC) for each diet and compared with the IAUC for glucose solution standard according to the method of Jenkins et al. (1981); Wolever and Jenkins (1986) and Wolever et al. (1991) which also reported by FAO (1997) using the following equation:

Incremental Area Under $2 \mathrm{~h}$ blood glucose Curve for food

$\mathrm{GI}=$

X 100

Incremental Area Under $2 \mathrm{~h}$ blood glucose Curve for glucose or white

bread

Statistical Analysis: The complete randomized design (CRD) was used. Statistical difference was determined using Duncan's multiple range test at $(\mathrm{p}<0.05)$ by SAS Version (1989)

\section{RESULTS AND DISCUSSION}

Bread is considered as one of the most important sources of carbohydrate in human diet even in normal or disease. Diabetes is usually required frequent meals in their therapeutic life, so bread is considered as one of the diet component that cannot discard (Bjorck et al., 1994). Relating to the subject of GI, most of the cereal products observed higher glucose and insulin responses (Jenkins et al., 1981 and Bjorck et al., 2000). However, bread and cereal products are confirmed to contain resistant starch and their content of this resistant starch are affecting by 


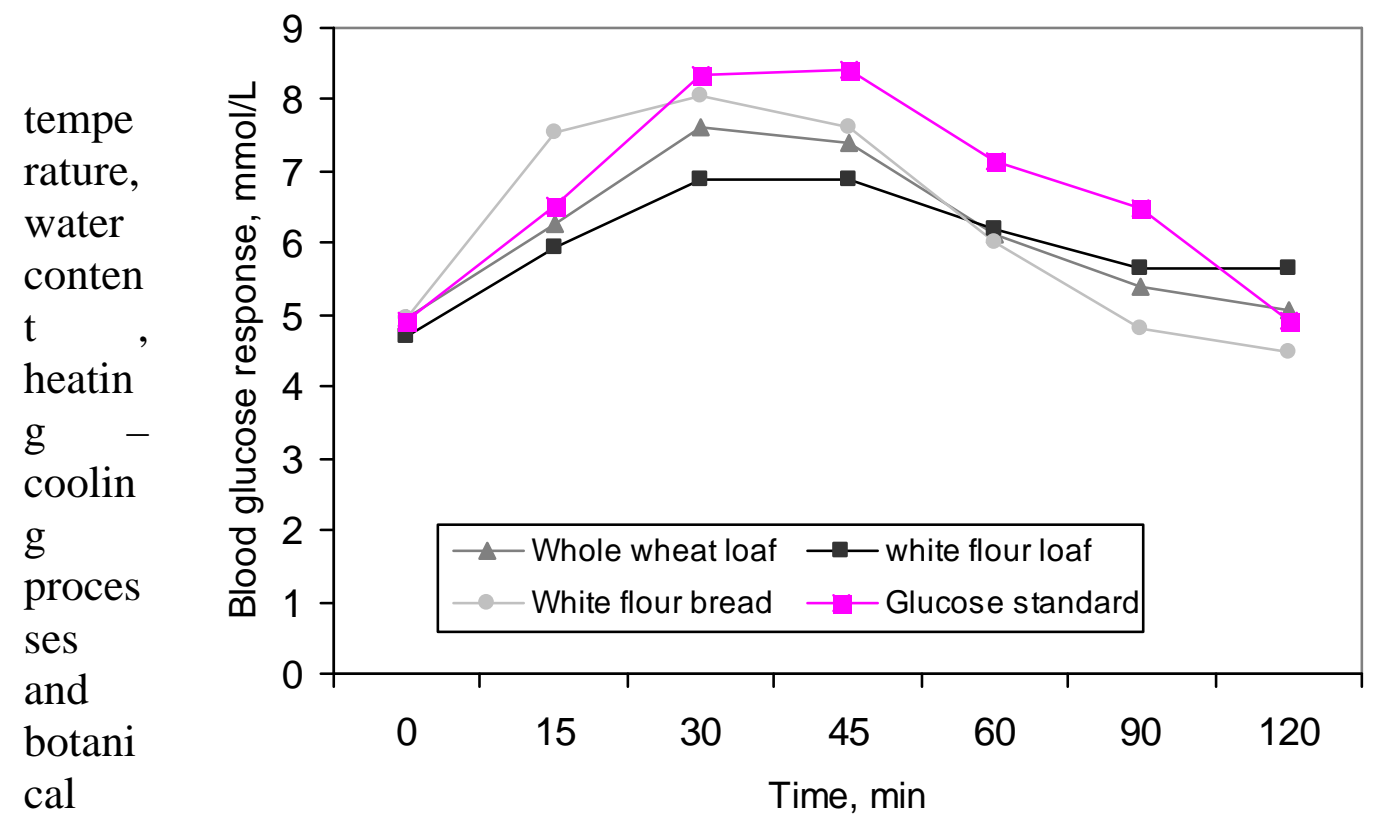

nature

of the

starch.

Figure 1: Blood glucose response of whole wheat loaf and bread for normal human subjects

The

serum glucose response curves for three kinds of loaves and bread; whole wheat loaves, white flour loaves and white flour bread 'Tannour' bread are shown in Figure 1 and Table 3. In all cases, there was a sharp increase in glucose responses especially for white flour bread to reach the highest mean values (7.60, 6.9 and $8.06 \mathrm{mmol} / \mathrm{L}$, respectively) $30 \mathrm{~min}$ after the beginning of the ingestion of the diets. Fifteen minutes later (at $45 \mathrm{~min}$ ), the glucose responses for all kinds of breads were begun to slow down or become constant. With more time to pass, decrease in the glucose responses are observed to reach near the base line ( 4.5 to $4.7 \mathrm{mmol} / \mathrm{L})$. The Table shows that there were no significant differences $(\mathrm{P}<0.05)$ in GI between the three kinds of loaves and bread (61, 69 and 64 for whole wheat loaf, white flour loaf and Tannour bread, respectively) but significantly lowers $(\mathrm{P}<0.05)$ than that of glucose standard (100). GI for whole wheat loaf (61) was lower than that of Tannour bread (64) and both were lower than that of white flour loaf (69). Similar conclusion was found by Behall et al. (1999) in which they found lower glucose response for white bread, ultra fine ground and whole wheat bread compare with glucose standard, however the differences were not significant $(\mathrm{P}<0.05)$. Table 3 also show that IAUC values $(141,160$ and $148 \mathrm{mmol} . \mathrm{min} / \mathrm{L}$ for whole wheat, white flour loaves and Tannour bread, respectively) for all these products were identical and consistent with the values of their GIs. In which there were no significant differences $(\mathrm{P}<0.05)$ between their IAUC values, but there were significant differences $(\mathrm{P}<0.05)$ with the IAUC value $(232 \mathrm{mmol} . \mathrm{min} / \mathrm{L})$ for glucose standard. 
Table 3: Blood glucose response, Incremental Area Under Curve (IAUC) and Glycemic index (GI) of loaves and bread for normal subjects.

\begin{tabular}{|l|c|c|c|}
\hline \multicolumn{1}{|c|}{ Food } & IAUC mmol.min/L & GIg & Gib \\
\hline Whole wheat loaf & $141 \mathrm{~b}$ & $61 \mathrm{~b}$ & 86 \\
\hline White flour loaf & $160 \mathrm{~b}$ & $69 \mathrm{~b}$ & 97 \\
\hline White flour bread (Tannour) & $148 \mathrm{~b}$ & $64 \mathrm{~b}$ & 90 \\
\hline Glucose standard & $232 \mathrm{a}$ & $100 \mathrm{a}$ & 141 \\
\hline
\end{tabular}

Same letters in the column (small letter) indicate that there is no significant difference $(\mathrm{p}<0.05)$

GIg Glycemic index when the standard is glucose solution. (GIb X 0.7 Foster-Powell and Brand Miller, 1995).

GIb Glycemic index when the standard is White bread. (GIg X 1.41 Foster-Powell and Brand Miller, 1995).

The results for white flour loaf are in agreement with that of Walker and Walker (1984) and Hallfrisch and Behall (2000) and similar to that of Jenkins et al. (1981) for whole wheat bread and in agreement with that of Jenkins et al. (1981); Walker and Walker (1984); Jenkins et al. (1986) and Ross et al. (1987) for whole wheat bread. Looking back to the Table 1 and 2, we can notice that there are differences in chemical composition of the three kinds of the flour and bread, which are made from. Whole wheat flour and loaf has more protein, fat and fiber than that of white flour. Moreover, this might be one of the factors that affecting the results. Braaten et al. (1991) found that GI for whole wheat bread containing boiled whole wheat grains was lower than that of white bread. However, Wolever and Bolognesi (1996a) concluded that variation in protein and fat intake over a certain range appears to have a negligible effect on postprandial glucose and insulin of normal subjects consuming mixed meals. Kestin et al. (1990) and Cara et al. (1992) stated that wheat bran did not show significant decrease in blood glucose response in which the most of these fibers might be insoluble that resulted in lower viscosity in the intestine but they increase the rate of intestinal emptying. Although the others (Wolever and Bolognesi, 1996b) concluded that both the amount and source of carbohydrate consumed are important determinants of postprandial glucose and insulin responses of mixed meals in normal subjects. Further, even though white flour loaf and Tannour bread were made from the same flour there was a difference 
in their GI and IAUC (71, 66 and 149, $160 \mathrm{mmol} . \mathrm{min} / \mathrm{L}$, respectively) and may be the reason of the method of processing and baking. In which differences in the method of cooking and processing of the foods have been considered a factors affected the blood glucose and insulin responses (Collings et al., 1981; Jenkins et al., 1986; Brand et al., 1985 and Darabi et al., 2000). Table 4 shows the amylose and amylopectin contents and the gelatinization temperature of the whole wheat and white flours that made the loaf and the bread.

Table 4: Amylose and amylopectin content of the starch and gelatinization temperature of the flours and wheat products.

\begin{tabular}{|l|c|c|c|c|c|}
\hline \multicolumn{1}{|c|}{ Food } & $\begin{array}{c}\text { Apparent } \\
\text { amylose } \\
\%\end{array}$ & $\begin{array}{c}\text { Amylopectin* } \\
\%\end{array}$ & $\begin{array}{c}\text { Total amylose } \\
\%\end{array}$ & $\begin{array}{c}\text { Amylopectin* } \\
\%\end{array}$ & $\begin{array}{c}\text { Gelatinization } \\
\text { temperature, } \\
\mathrm{C}^{\mathrm{o}}\end{array}$ \\
\hline $\begin{array}{l}\text { Whole wheat } \\
\text { flour }\end{array}$ & $24.1 \mathrm{a}$ & $\mathrm{v}^{\circ} .9 \mathrm{a}$ & $26.8 \mathrm{a}$ & $73.2 \mathrm{a}$ & $64.5 \mathrm{~b}$ \\
\hline White flour & $24.9 \mathrm{a}$ & $75.1 \mathrm{a}$ & $26.8 \mathrm{a}$ & $73.3 \mathrm{a}$ & $63.5 \mathrm{~b}$ \\
\hline Burghul & $\mathrm{nd}$ & $\mathrm{nd}$ & $\mathrm{nd}$ & $\mathrm{nd}$ & $\mathrm{nd}$ \\
\hline Habbiyah & $26.3 \mathrm{a}$ & $73.7 \mathrm{a}$ & $28.0 \mathrm{a}$ & $72.0 \mathrm{a}$ & $68.0 \mathrm{~b}$ \\
\hline Reshta & $23.3 \mathrm{ab}$ & $74.7 \mathrm{a}$ & $25.7 \mathrm{ab}$ & $74.3 \mathrm{a}$ & $82.5 \mathrm{a}$ \\
\hline Spaghetti & $27.8 \mathrm{a}$ & $72.2 \mathrm{a}$ & $29.2 \mathrm{a}$ & $70.8 \mathrm{a}$ & $63.5 \mathrm{~b}$ \\
\hline
\end{tabular}

nd: Not determined. $*$ By difference.

Same letters in the column indicates that there is no significant difference $(p<0.05)$.

The Table shows almost similar values and there were no significant differences $(\mathrm{P}<0.05)$ among amylose and amylopectin values for both flours in this study. It has been noticed that amylose of the starch has been shown to be digested more slowly than amylopectin (Behall et al., 1988 and 1989). Similar finding was noticed with the degree of the gelatinization. The high temperature of gelatinization of the starch granules of the products, the higher the GI (Ross et al., 1987).

Figure 2 and Table 5 show the average blood glucose response for 120 min after ingestion of tested wheat products namely, burghul, habbiyah, reshta and spaghetti. 


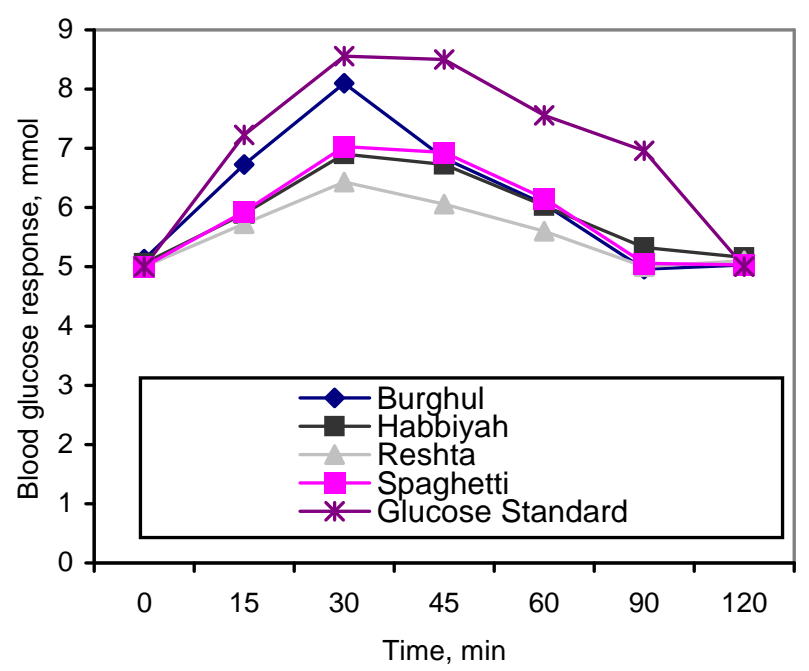

Figure 2: Blood glucose response of some wheat products for normal human subjects

Table 5: Blood glucose response, Incremental Area Under Curves (IAUC) and Glycemic Index (GI) of some wheat products for normal subjects.

\begin{tabular}{|l|c|c|c|}
\hline \multicolumn{1}{|c|}{ Food } & IAUC mmol.min/L & GIg & GIb \\
\hline Burghul & $107 \mathrm{~b}$ & $41 \mathrm{~b}$ & 58 \\
\hline Habbiyah & $102 \mathrm{~b}$ & $40 \mathrm{~b}$ & 56 \\
\hline Reshta & $66 \mathrm{~b}$ & $26 \mathrm{~b}$ & 37 \\
\hline Spaghetti & $103 \mathrm{~b}$ & $40 \mathrm{~b}$ & 56 \\
\hline Glucose standard & $258 \mathrm{a}$ & $100 \mathrm{a}$ & 141 \\
\hline
\end{tabular}

Same letters in the column (small letter) indicate that there is no significant difference at $(\mathrm{p}<0.05)$.

GIg Glycemic index when the standard is glucose solution. (GIb X 0.7 Foster-Powell and Brand Miller, 1995)

GIb Glycemic index when the standard is White bread. (GIg X 1.41 Foster-Powell and Brand Miller, 1995)

Results show that within 30 min after ingestion of the wheat products, the blood glucose response was prompt increased especially for burghul to reach the highest values of $8.1,6.9,6.43$ and $7.03 \mathrm{mmol} / \mathrm{L}$ for burghul, habbiyah, reshta and spaghetti, respectively compare with $8.56 \mathrm{mmol} / \mathrm{L}$. for glucose standard. The Table shows that at this time there were no significant differences $(\mathrm{P}<0.05)$ between the values. Negligible decrease in the values of blood glucose responses were occurred 30 to $45 \mathrm{~min}$ after ingestion before starting to dropping down to reach close the value of $5.0 \mathrm{mmol} / \mathrm{L}$ with all wheat products after $90 \mathrm{~min}$ of ingestion. In which blood glucose response for glucose standard remained higher $(6.96 \mathrm{mmol} / \mathrm{L})$ than this value $90 \mathrm{~min}$ before dropping down to $5.00 \mathrm{mmol} / \mathrm{L}$ at $120 \mathrm{~min}$ of ingestion of the foods. Table 5 also shows the IAUC and GI for the wheat products and glucose standard. It has been noticed that there were no significant differences $(\mathrm{P}<0.05)$ between both values of IAUC (107, 102, 66 and $103 \mathrm{mmol}$. min/L for burghul, habbiyah, reshta and spaghetti, respectively) and GI (41, 40, 26 and 40 for bulghul, habbiyah, reshta and spaghetti, respectively) compare with significant 
$(\mathrm{P}<0.05)$ higher values of IAUC $(258 \mathrm{mmol} . \mathrm{min} / \mathrm{L})$ and GI $(100)$ for glucose standard. Results show that the highest GI value (41) was for burghul and lowest value (26) for reshta within the four wheat products compare with 69 and 100 for white flour loaf (bread) and glucose standard (Table 3).

The results show that GI values for burghul and habbiyah were lower than the values found by Jenkins et al. (1986) and Wolever et al. (1987) and very close to those mentioned by Foster-Powell and Brand-Miller (1995). The results also show that GI value for spaghetti was much closed to that of Jenkins et al. (1981); Bornet et al. (1987); Wolever et al. (1987) and Granfeldt and Bjorck (1991). Whereas, the low GI value for reshta was much less than those mentioned by Foster-Powell and Brand-Miller (1995). As we mentioned above that method of food processing and cooking were considered as important factors in the different glucose responses for the foods. Specifically, the differences in the method of processing such as water availability, heating temperature, method of heating, length of cooking and differences in particle size and gelatinization of the starchy foods all these help to explain the variability of blood glucose responses and the value of GI. Precooking by blanching of whole wheat in processing of Burghul and habbiyah in the presence of endosperm cover before drying and grinding of the grains could prevent complete gelatinization of starch which resulting in lowering of GI (Jenkins et al., 1986). Jenkins et al. (1988) and Granfeldt et al. (1995) referred that boiling the whole grains of wheat, oat, rye and barley resulted in lowering blood glucose and insulin responses. Further, the presence of whole wheat grains in the bread resulted in lower GI values compare with white bread (Liljeberg et al., 1992). Moreover, burghul and habbiyah which are made from partial dehull whole wheat grains had lower blood glucose response and GIs compare with those of breads especially white bread. This method of food processing may be have possible way to keep some of the natural components of the whole wheat grains such as protein, fat, fiber, antinutritional factors such as trypsin inhibitor, phytic acid and chemical nature of the other polysacharides and all these components may appear to make differences in the GI values by limiting the digestion and absorption of glucose in the gut (Thompson et al., 1983; Yoon et al., 1983; Cara et al., 1992 and Darabi et al., 2000).

The shape of the foods especially cereal products has their effects on the GI values, since the GI for reshta and spaghetti is about $50 \%$ of that of GI value for bread although their flour composition are the same. Sarface area and particle size of the granules, water availability and baking of the bread are other factors have to concern in hydration, gelatinization, and therefore hydrolysis of the starch (Snow and O'Dea, 1981; Brand et al., 1985; Heaton et al., 1988; Holm et al., 1988 and Darabi et al. ,2000). Lower GI (26) for reshta compare with spaghetti (40) was noticed (Table 5) and this might be because of more amylose in spaghetti than reshta even though the gelatinization temperature of the spaghetti is lower $\left(63.5 \mathrm{C}^{\circ}\right)$ than reshta $\left(82.5 \mathrm{C}^{\circ}\right)$ (Table 4). Further, refer to the Table 1 and 2, reshta contained more respective values of protein (15.3 and $9.7 \%$ ) than spaghetti (11.56 and $7.4 \%)$ and reshta also contained more respective values of fiber $(2.51$ and $1.59 \%)$ than spaghetti $(0.36$ and $0.23 \%)$ 
and these might be added reasons in which more protein resulted in stimulation of insulin secretion, or affecting the rate of small intestinal glucose uptake and therefore lowering the GI value (Potter et al.,1981; Nuttall et al., 1984 and Wolever and Bolongnesi, 1996a).

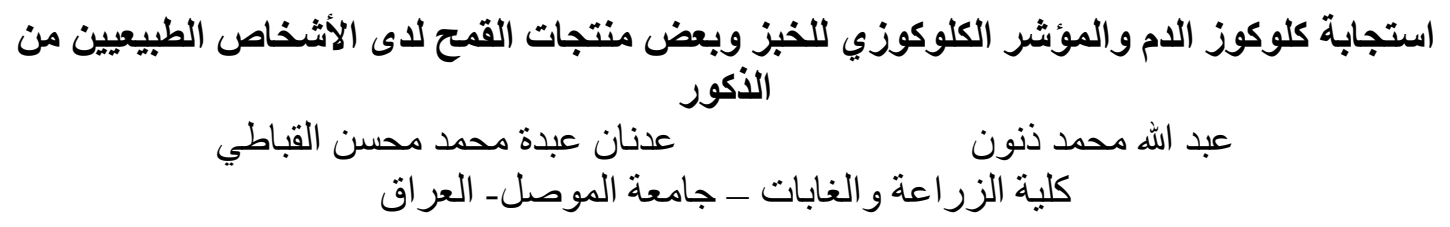

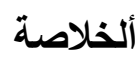

تم دراسة استجابة كلوكوز الدم وتقدير المؤشر الكلوكوزي لبعض ألعانئ أنواع الخبز أو الصمون وكذللك

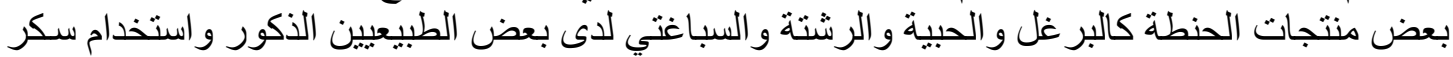

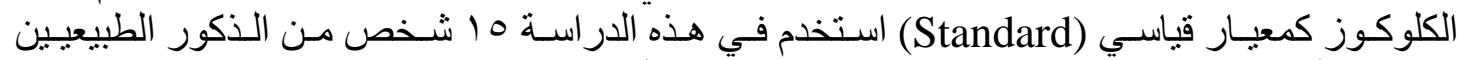

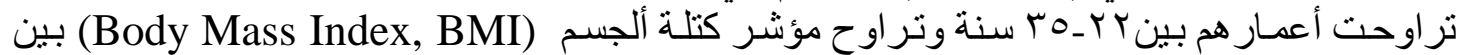

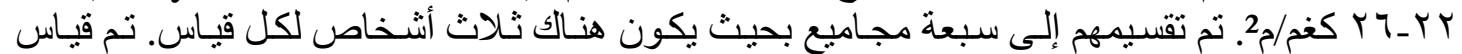

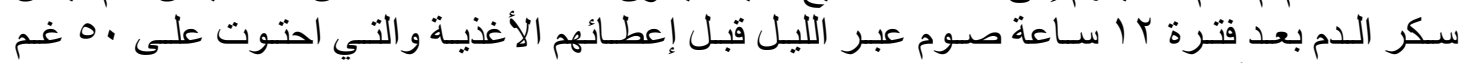

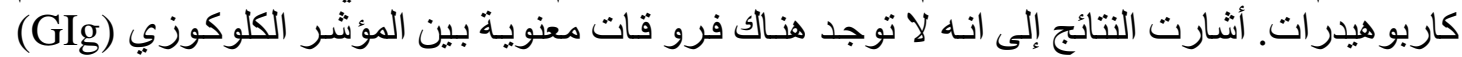

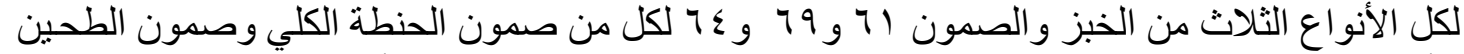

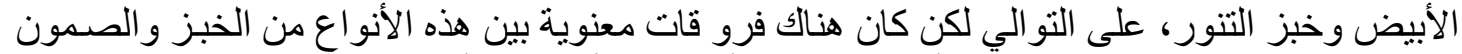

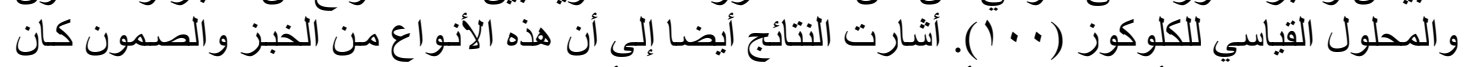

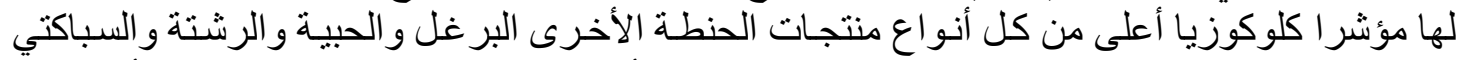

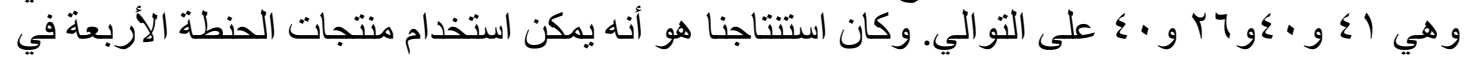
برنامج تغذية المصابين بداء السكر من نوع الثاني Type II diabetes.

\section{REFERENCES}

AACC (1976). Approved method of American Association of Cereal Chemists. St. Paul, MN, USA..

AOAC (1980). Association of Official Analytical Chemists. Official Methods of Analysis. $13^{\text {th }} \mathrm{Ed}$ Assoc. of Official Analyst. Chem. Washington D. C. USA..

Behall, K. M.; D. J. Scholfield and J. Canary (1988). Effect of starch structure on glucose and insulin responses in adult. Am. J. Clin Nutr., 47: 428-432.

Behall, K. M.; D. J. Scholfield; I. Yuhaniak and J. Canary (1989). Diets containing high amylose vs amylopectin starch effects on metabolic variables in human subjects. Am. J. Clin. Nutr., 49: 337-344.

Behall, K. M. D. J. Scholfield and J. Hallfrisch (1999). The effect of particle size of whole grain flour on plasma glucose, insulin and TSH in human subjects. J.

Am. Coll. Nutr., 18: 591-597.

Bjorck, I.; M. Nyman; B. Pederson; M. Siljestorm; N Asp and B. Eggum (1986). On the digestibility of starch in wheat bread study in vitro and in vivo. J of Cereal Sci., 4: 1-11. 
Bjorck, I.; Y. Granfeldt; H. Liljeberg; J. Tovar and N. Asp (1994). Food properties affecting the digestion and absorption of carbohydrates. Am. J. Clin. Nutr., 59: 699-705.

Bjorck, I.: H. Liljeberg and E. Ostman (2000). Low glycemic index foods. Brit. J. $\quad$ Nutr., 83: 1495-1555.

Bornet, F. R. J.; D. Costagliola; A. Blayo; S. Rizkalla; A. M. Fontveille; M. J. Haardt; M. Letonoux; G. Tehobroutsky and G. Slama (1987). Insulinogenic and glycemic indices of six starch-rich foods taken alone and in amixed meal by type 2 diabetics. Am. J. Clin. Nutr., 45: 588-595.

Bourdon, I.; W. Yokoyama; P. Davis; C. Hudson; R. Bockus; D. Richter; B. Knuckles and B. O. Schneeman (1999). Postprandial lipid, glucose, insulin and cholrcystokinin responses in men fed barley pasta enriched with beta-glucan. $\quad$ Am. J. Clin. Nutr., 69: 55-63.

Braaten, J. T.; P. J. Wood; F. W. Scott; D. Riedel; L. M. Poste and M. W. Collins (1991). Oat gum lowers glucose and insulin after and oral glucose load. Am. J. Clin. Nutr., 53: 1425-1430.

Brand, J. C.; P. L. Nicholson; A. W. Thorburn and A. S. Truswell (1985). Food processing and glycemic index. Am. J. Clin. Nutr., 24: 43-54.

Cara, L.; C. Dubois; P. Borel; M. Armand; M. Senft; H. Portugel; A. M. Pauli; P. M. Bernard and D. Lairon (1992). Effect of oat bran, rice bran, wheat fiber and wheat germ on postprondial lipemia in healthy adult. Am. J. Clin. Nutr., 55: 81-88.

Collings, P.; C. Williams and I. MacDonalds (1981). Effect of cooking on serum glucose and insulin responsesto starch. Br.Med. J., 282: 1032.

Crapo, P.; J. Insel; M. Sperling and O. Kolterman (1981). Comparison of serum glucose and insulin responses to various carbohydrate containing foods. A. J. Clin. Nutr., 34: 184-190.

Darabi, A.; F. A. Taleban; M. Esmaili and N. Valaii (2000). Glycemic index of split peas, rice (binam), kidney beans, grean peas, "Lavash" bread and broad bean kernels in NIDDM subjects. Acta Medica Iranica 38: $79-83$.

FAO (1997). Food and Agriculture Organization. Carbohydrate in human nutrition. FAO Food and Nutrition Paper - 66. Report of a joint FAO/WHO Expert Consultation, Rome 14-18 April, 1997.

Foster-Powell, K. and J. C. Brand Miller (1995). International tables of glycemic index. Am. J. Clin. Nutr., 62: 871S-893S.

Foster-Powell, K; S. H. A. Holt and J. C. Brand Miller (2002). International table of glycemic index and glycemic load values; 2002. Am. J. Clin. Nutr., 76: 5-56.

Grannfeldt, Y. and I. Bjorck (1991). Glycemic response to starch in pasta: a study of mechanism and limited enzyme availability. J. Cereal Sci., 14: 47-61. 
Granfeldt, Y; B. Hagander and I. Bjorck (1995). Metabolic responses to starch in oat and wheat products on the importance of food structure: in complete gelatinization or presence of viscous dietary fiber. Eur. J. Clin. Nutr., 49: 189- 199.

Halfrisch, J. and K. M. Behall (2000). Mechanism of the effects of grains on insulin and glucose response. J. Am. Coll. Nutr., 19: 320-325.

Heaton, K. W.; S. N. Marcus; P. M. Emmett and C. H. Botton (1988). Particle size of wheat, maize and oat test meals: effects on plasma glucose and insulin responses and on the rate of starch digestion in vitro. Am. J. Clin. Nutr., 46:

675-682.

Holm, J.; I. Lundguist and I. Bjorck (1988). Degree of starch gelatinization digestion rate of starch in vivo and metabolic response of rats.. Am. J. Clin. Nutr., 46: 1010-1016.

Jenkins, D. J. A.; T. M. S. Wolever and R. H. Taylor (1981). Glycemic Index of food a physiological basis for carbohydrate exchange. Am. J. Clin. Nutr., 34: 362- 366.

Jenkins, D. J. A.; M. J. Thorne and K. Camelon (1982). Effect of processing on digestibility and the blood glucose response: a study of lentils. Am. J. Clin. $\quad$ Nutr., 36: 1093-1101.

Jenkins, D. J. A.; T. M. S. Wolever and J. Kalmusky (1985).Low glycemic index carbohydrate foods in the management of hyperlipidemia. Am. J. Clin. Nutr., 42: 604-617.

Jenkins, D. J. A.; T. M. S. Wolever and A. L. Jenkins (1986). Low glycemic index response to traditionally processed wheat and rye products: bulghur and pumpernickel bread. Am. J. Clin. Nutr., 43: 516-520.

Jenkins, D. J. A.; T. M. S. Wolever; G. R. Collier; A. Ocana; A. V. Rao; G. Buckley; Y. Lam; A. Mayer; and L. U. Thompson (1987). Metabolic effects of a low glycemic index diet. Am. J. Clin. Nutr., 46: 968-975.

Jenkins, D. J. A.; T. M. S. Wolever and G. C. Buckley (1988). Low glycemic index starchy foods in the diabetic diet. Am. J. Clin. Nutr., 48: 4854.

Johnson, V. A. and P. J. Mattern (1987). Wheat, Rye, and Triticale. In Nutritional Quality of Cereal Grains: Genetic and Agronomy Important, Ed by Olsen R. A. and K. J. Frey. American Societay of Agronomy, Inc. and Others, Madison, Wisconson, USA.

Kestin, M.; R. Moss; P. M. Difton and P. J. Nestel (1990). Comparative effects of three cereal bran on plasma lipids, blood pressure and glucose metabolism in mildly hypercholesterolemic subjects. Am. J. Clin. Nutr., 52: 661-666.

Liljeberg, H.; Y. Granfeldt and I. Bjorck (1992). Metabolic responses to starch in bread containing intake kernels versus milled flour. Eur. J. Clin. Nutr., 46: 561-575.

Morrison, W. R.; R. F. Tester; C. E. Snape; R. Law and M. G. Gidly (1988). Swelling and gelatinization of cereal starches I. V. So, e effect of 
lipid complexed

amylose and free amylose in waxy and normal barley starches. Cereal Chem., 70: 385-390.

Nuttal, F.; A. Mooradian; M. Gannon; C. Billington and P. Krezowaki (1984). Effect of ingestion on the glucose and insulin response to a standardized oral glucose load. Diabetes Care, 7: 465-470.

O'Dea K.; P. J. Nestel and L. Antonoff (1980). Physical factors influence postprandial glucose and insulin responses to starch. Am. J. Clin. Nutr., 33: 760-765.

Pearson D. (1973). Laboratory technique in food analysis. Tingling and Co. LTD. London.

Pearson D. (1976). The Chemical Analysis of Food. Churchill, Livingstone, NY, USA..

Potter, J. G.; K. P. Coffman; R. L. Reid; J. M. Krall and K. M. J. Albrin (1981). Effect of test meals of varying dietary fiber content on plasma insulin and glucose response. Am. J. Clin. Nutr., 34: 328-334.

Roderuck, C. E. and H. Fox (1987). Nutritional value of cereal grains. In Nutritional Quality of Cereal Grains: Genetic and Agronomic Important. Ed by Olsen R. A. and K. J. Frey. American Society of Agronomy, Inc. and others Madison, Wisconson, USA..

Ross, S. W.; J. C. Brand; A. W. Thorburn and A. S.Truswell (1987). Glycemic index of processed wheat product. Am. J. Clin. Nutr., 46: 631-635.

Russell, P. L.; C. S. Berry and P. Greenwell (1989). Characterization of resistant starch from wheat and maize. J. of Cereal Sci., 9: 1-15.

SAS Institute Inc. (1989). Statistical Analysis System. SAS/Stat guide for personal computer. Cary, NC, USA.

Smolin, L. A. and M. B. Grosvenor (2003). Nutrition Science and Application $4^{\text {th }}$ Ed John Wiley \& Sons, Inc. USA.

Snow, P. and K. O'Dea (1981). Factors affecting the rate of hydrolysis of starch in food. Am. J. Clin. Nutr., 34: 2721-2727.

Thompson, L. U.; J. H. Yoon and D. J. A. Jenkins (1983). Relationship between polyphenol intake and food blood glucose response of normal and diabetic individual. Am. J. Clin. Nutr., 39: 745-751.

Walker, a. R. P. and B. R. Walker (1984). Glycemic index of South African foods determined in rural blacks a population of low risk to diabetes. Hum. Nutr. Clin. Nutr., 36: 215-222.

Wolever, T. M. S. and D. J. A. Jenkins (1986). The use of the glycemic index in predicting the blood glucose response to mixed meals. Am. J. Clin. Nutr., 43: $167-172$.

Wolever, T. M. S.; D. J. A. Jenkins; R. G. Rosse; G. S. Wong and R. Lee (1987). Theglycemic index: similarity of values derived in IDDM and NIDDM patients. J.Am. Coll. Nutr., 6: 295-305.

Wolever, T. M. S.; D. J. A. Jenkins; A. L. Jenkins and R. G. Josse (1991). The glycemic index: methodology and clinical implications. Am. J. Clin. Nutr., 54: 846-854.

Wolever, T. M. S.; D. J. A. Jenkins; V. Vuksan; A. L. Jenkins; G. C. Buckley; G. S. Wong; R. G. Josse (1992). Beneficial effect of low glycemic index diet in type2 diabetes. Diabetic Med., 9: 451-458.

Wolever, T. M. S.; L. Katzman-Relle and A. L. Jenkins (1994). Glycemic index of 102 complex carbohydrate foods in patients with diabetes. Nutr. Res., 14: 651669. 
Wolever, T. M. S. and C. Bolognesi (1996a).Prediction of glucose and insulin responses of normal subjects after consuming mixed meals varying in energy, protein, fat, carbohydrate and glycemic index. J. Nutr., 126: 2807-2812.

Wolever, T. M. S. and C. Bolognesi (1996b). Source and amount of carbohydrate affect postprandial glucose and insulin in normal subjects. J. Nutr.,126: 27982706.

Yoon, J. H.; L. U. Thompson and D. J. A. Jenkins (1983). The effect of phytic acid on in vitro rate of starch digestibility and blood glucose response. Am. J. Clin. Nutr., 38: 835-844. 